\title{
Growing out of the crisis: hidden assets to Greece's transition to an innovation economy
}

\author{
Benedikt Herrmann ${ }^{1}$ and Alexander S Kritikos ${ }^{2 *}$
}

\footnotetext{
*Correspondence: akritikos@diw.de ${ }^{2}$ German Institute for Economic Research (DIW Berlin), University of Potsdam, Potsdam, Germany Full list of author information is available at the end of the article
}

\begin{abstract}
Greece's currently planned institutional reforms will help to get the country going with limited economic growth. With an economy based primarily on tourism, trade, and agriculture, Greece lacks an established competitive industry and an innovation-friendly environment, resulting in a low export ratio given the small size of the country and its long-time EU-membership. Instead, Greece exports only its nation's talent, with low returns. To become prosperous, the country must better capitalize on its Eurozone membership and add innovative sectors to its economic structure. Given Greece's hidden assets, such as the attractiveness of the country, a small number of strong research centers and an impressive diaspora in research, finance and business, we envision a Greek "Silicon Valley" and propose a ten point policy plan to achieve that goal.

JEL codes: L2, L26, O3, O4.

Keywords: Innovation; Greece; Growth strategy; Entrepreneurship; Innovation systems; Regulatory environment
\end{abstract}

\section{Introduction}

Although Greece is showing initial signs of recovering from its 2008 crash following the reforms imposed by the troika, its economy continues to suffer. As of the end of the year 2012, Greece's Gross Domestic Product (GDP) has declined, cumulatively, by more than twenty percent, with unemployment exceeding 27 percent in the summer of 2013.

A raft of policy recommendations were identified and debated, all seeking to help the Greek economy find its way out of the crisis. Institutional reforms, in particular the liberalization of closed professions, wage reductions, and the privatization of public industries, are meant to help improve the competitiveness of the Greek economy. However, the economy will not become prosperous only by cutting costs and making institutional reforms, as much as these are needed. The central problem is the lack of an established industry structure and a well-functioning innovation system. If nothing else changes, the country will have a steady, tourism-based economy supplemented by a food manufacturing base. These components will not yield substantial prosperity increases for the Greek society.

At the same time we observe a considerable number of scientists who are able to conduct cutting edge research in Greece along with a tiny number of high tech industries. Although embroiled in the current difficulties of administrative provisions, these firms create highly valuable products in Greece. We also observe that the Greek 
diaspora includes a significantly larger number of scientists working at leading research institutions and high tech companies in the US and across Europe. Moreover, the country disposes of a unique asset when it comes to win the international race for talents: the attractiveness of its quality of life.

We argue that Greece is at a crossroads: it can either choose to focus on tourism only, emulating the example of Orlando, Florida, or to be ambitious and follow the example of San José, California, by using the same assets that attract tourists to attract talented individuals with unique skills from over the world. Such commitment by Greek authorities will transform Greece into an innovation-based economy producing technological breakthroughs that create added value in high-tech and knowledge-intensive industries. To achieve this goal, Greece needs to develop an innovation system by implementing a specific set of policy measures encompassing, inter alia, (i) the further development of existing and the establishment of new research institutes, universities and professional education of the highest quality; (ii) the expansion of research clusters based on existing specialization within Greece; (iii) business environment reforms including improved (intellectual) property rights, aimed at nurturing the entry and growth of innovative firms and businesses; (iv) the development of financial tools to support actors in the early stage of innovation; and (v) the development of a Diaspora policy toward Greek researchers, investors and business owners living outside of Greece. For many, the vision of Greece as European "Silicon Valley" might appear as a pipe-dream. As we argue in this paper, such a plan is both desirable and achievable when provided with the political will and perseverance to make it a reality.

The rest of the paper is organized as follows. Section 2 presents a short review of the current economic situation in Greece, making clear why austerity measures and institutional reforms are necessary but not sufficient. Section 3 describes why focusing on innovation is a key ingredient for getting Greece on a path toward long-term economic growth. Section 4 presents a specific policy plan in how to make Greece more innovative. Section 5 concludes.

\section{Current situation in Greece}

Greece - like other economies - faced a severe recession in 2009, which turned in Greece into a sovereign debt crisis. The Troika of the European Union, the European Central Bank and the International Monetary Fund came into action with the goal of preventing Greece from bankruptcy. This Troika monitoring its public deficit negotiated a list of severe austerity measures and economic and institutional reforms to attain fiscal consolidation. ${ }^{1}$ Several austerity measure targets have been achieved and initial successes reported. The labor cost structure of the Greek economy and its current account balance were substantially improved. The nominal unit labor costs (Figure 1), which were in 2001 relatively low in Greece, peaking at the beginning of 2010, dropped significantly in 2012 with reforms having reduced wages compared to previous years (Buti and Turrini, 2012). The current account deficit (Figure 2), which had started to become negative before the financial crisis, has been cut in size over the last three years and, at the end of 2012, was close to zero. Similarly, the public deficit was significantly decreased. Currently, in the first half year of 2013, public revenues (without debt service) exceed public expenditures by 2.6 Billion Euros (European Commission, 2013).

Beyond these initial reform successes, the current economic situation in Greece is shown in Figure 3: in 2010, 2011, and 2012 GDP shrank by more than 5 percent. The 


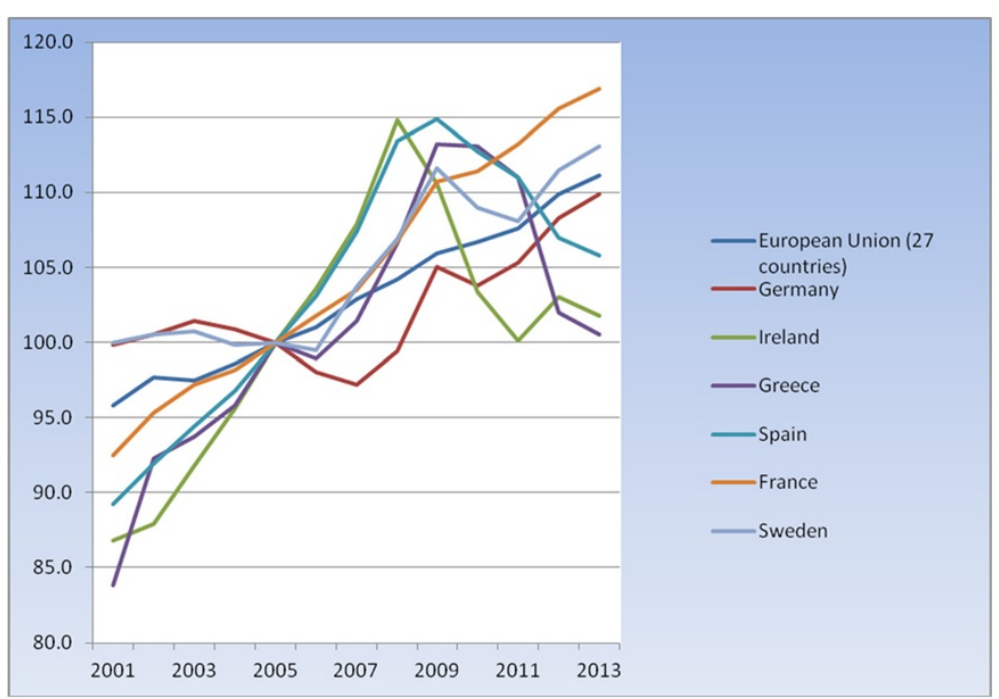

Figure 1 Nominal unit labor costs: Greece currently with the lowest labor costs. Source: Eurostat (2012).

labor market situation is devastating. Around $27 \%$ of the registered work force is, as of July 2013, unemployed. ${ }^{2}$ The best educated people are leaving the country, with other EU-countries taking advantage of this outward migration and it is observed that these migrants are often better qualified than their German counterparts. ${ }^{3}$ The negative development of the Greek economy in terms of GDP and unemployment resembles a depression. Still, many experts expect that the Greek economy will start recovering only by enforcing further institutional reforms, thus unleashing competitive forces and by doing 'more of the same' in terms of economic outcomes. Along this line, the further Troika reform program consists of a privatization package and of the opening of several closed professions and the liberal trades.

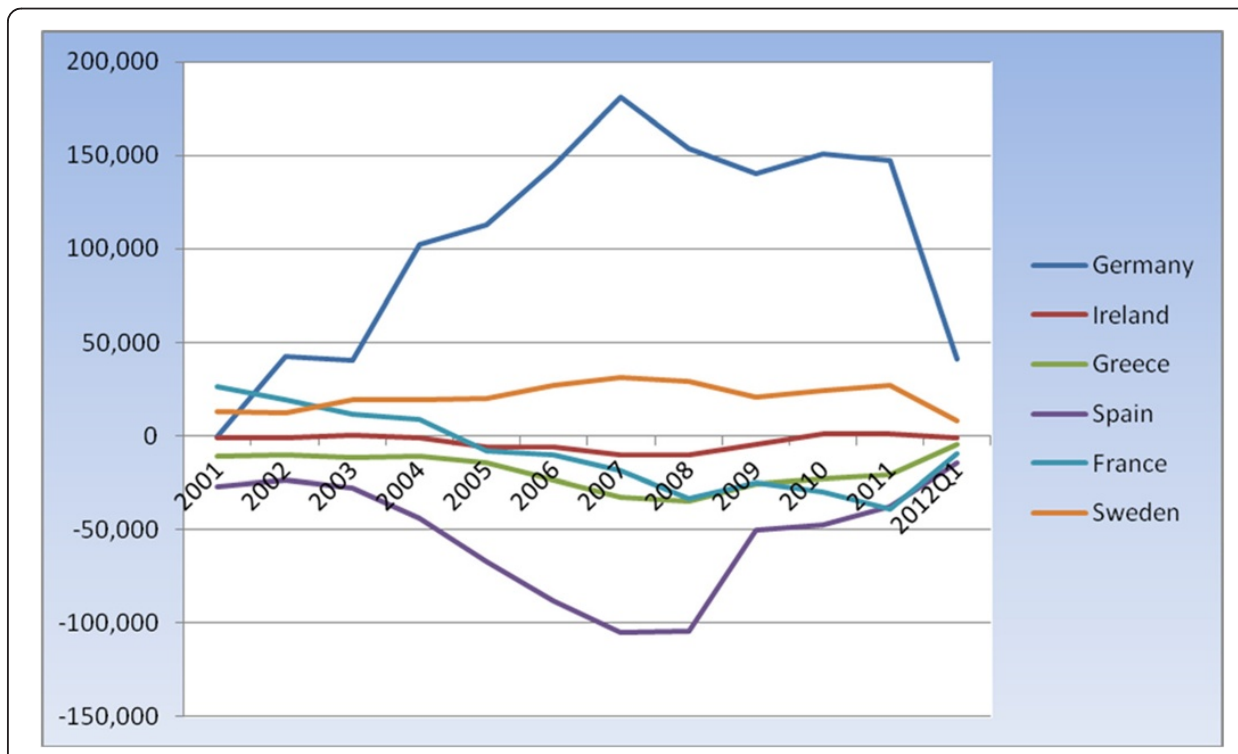

Figure 2 Current account balance. Source: Eurostat (2012). 


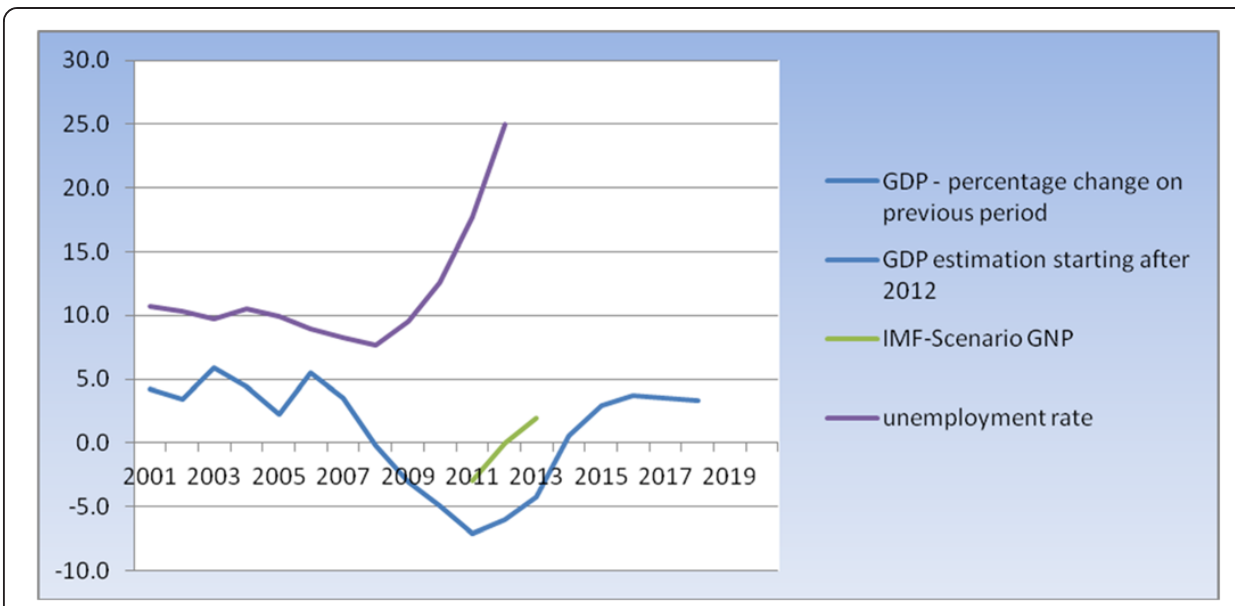

Figure 3 Development of GDP and of Unemployment in Greece. Sources: Eurostat (2012), IMF (2013).

An overview of the pre-crisis Greek economic structure raises concerns, however, of whether institutional reforms alone can transform Greece into a sustainably growing economy, able to pay back its public debt over a reasonable time frame. Table 1 presents the share of selected activities of gross value added as a percentage. Comparing these shares to EU averages and select countries, like Finland, Greece experienced a substantial drop in the manufacturing industry production share, from 18\% to 10\%; in Finland, this still accounts for $18 \%$ of the economy. The table also reveals that Greece is relatively specialized in agriculture and tourism (represented by the 'catering and hotel industry' sector), with both shares far above the EU average. ${ }^{4}$ There are also - albeit few - IT businesses in Greece (getting $40 \%$ of all R\&D investments) that, along with similarly small scale high tech companies in other areas, might be the nucleus for economic expansion, but are currently too small to develop sufficiently if only institutional reforms are continued.

Taking a closer look at the manufacturing industry, clarifies why Greece is in such deep trouble. The production of food, beverages and tobacco products is the largest single piece of Greek manufacturing, covering one third of the already small manufacturing sector; in the EU these average at 10 percent (Table 2). ${ }^{5}$ At the other end of the scale, we find that the production of machinery and electrical equipment each represent about 2 percent of the entire Greek economy, far below the EU average. The only substantial industrial manufacturing consists of paper and printing as well as the processing of mineral oil, and of metal products (Table 3 ).

Table 1 Share of selected economic activities of gross value added in percentage

\begin{tabular}{lccccc}
\hline Agriculture, forestry \\
and fishing
\end{tabular}

Source: Eurostat (2012), Calculations of DIW Berlin. 
Table 2 Structure of gross value added in manufacturing industry 2010 in percentage

\begin{tabular}{lcc}
\hline & Greece & EU \\
\hline Food products; beverages, tobacco products & 33.3 & 13.7 \\
Textiles, wearing apparel, leather and leather related products & 4.7 & 4.1 \\
Wood, paper, printing & 10.3 & 7.3 \\
Mineral oil & 10.5 & 1.2 \\
Chemical and chemical products & 4.3 & 6.9 \\
Pharmaceutical products & 5.6 & 4.6 \\
Rubber and plastic products, other non-metallic mineral products & 8.0 & 9.0 \\
Basic metals, fabricated metal products & 12.5 & 14.2 \\
Computer, electronic and optical products & 0.6 & 4.4 \\
Electrical equipment & 2.5 & 5.4 \\
Machinery and equipment & 2.0 & 10.9 \\
Motor vehicles, trailers and semi-trailers, transport equipment & 1.9 & 9.4 \\
Furniture, jewellery, musical instruments, games and toys; repair & 3.8 & 9.0
\end{tabular}

Source: Eurostat (2012), Calculations of DIW Berlin.

Further information on the structure of the manufacturing sector comes in form of the firm size in terms of employees (Table 3). While, for instance, in Finland the majority of individuals work for companies with at least 250 employees, it is the opposite in Greece. Even in manufacturing nearly 50\% work for a firm with 9 or fewer employees, unable to take advantage of increasing returns to scale. ${ }^{6}$ Moreover, it is argued that small countries need - due to the advantages of specialization in few areas - larger export ratios when compared to larger economies. In this line, the Netherlands have an export ratio of 70 percent and Finland of more than 40 percent. Greece has only a low share of tradable goods and services in GDP terms, resulting in a low average export to GDP ratio of only 22 percent between 2001 and 2010 (Table 4). Recent Eurostat figures indicate at least an increase to 27 percent. Greece managed to maintain a closed economy, despite having joined the European Union in 1981, revealing the structural problems underlying the Greek economy. An economy of its size, fully integrated in the EU, should have produced much larger export shares over time.

The picture of the Greek economy is completed by information on expenditures in consumption (Table 4) related to GDP. In Greece, final consumption represents 90 percent of GDP, far above average (Euro-zone average is 77 percent), with excessive public consumption making clear that the investment level in Greece, in particular for R\&D, is far below most other Euro-zone economies.

Table 3 Distribution of labor force in the manufacturing industry depending on firm size 2007

\begin{tabular}{lccccc}
\hline & \multicolumn{5}{l}{ Enterprises with ... employee } \\
\cline { 2 - 6 } & $\mathbf{1}$ to $\mathbf{9}$ & $\mathbf{1 0}$ to $\mathbf{1 9}$ & $\mathbf{2 0}$ to $\mathbf{4 9}$ & $\mathbf{5 0}$ to $\mathbf{2 4 9}$ & $\mathbf{2 5 0}$ and more \\
\hline Greece & 46 & 4 & 9 & 20 & 21 \\
Germany & 7 & 8 & 7 & 25 & 53 \\
Finland & 9 & 6 & 10 & 24 & 51 \\
\hline
\end{tabular}

Source: Eurostat, Calculations of DIW Berlin. Source: Eurostat (2012), Calculations of DIW Berlin. 
Table 4 Information on final consumption, export ratios, product market regulations and barriers to entry in services

\begin{tabular}{lcccc}
\hline & $\begin{array}{c}\text { Final Consumption } \\
\text { (\% of GDP) } \\
\mathbf{2 0 0 1 - 2 0 1 0 ~} \mathbf{~ a v g}\end{array}$ & $\begin{array}{c}\text { Exports } \\
\text { (\% of GDP) } \\
\mathbf{2 0 0 1 - 2 0 1 0} \\
\text { avg }\end{array}$ & $\begin{array}{c}\text { Product market } \\
\text { regulation } \\
\mathbf{2 0 0 8}\end{array}$ & $\begin{array}{c}\text { Barriers to entry in } \\
\text { services } \\
\text { 2008 }\end{array}$ \\
\hline Greece & 89.38 & 22.33 & 2.3 & 4.0 \\
Netherland & 73.04 & 70.06 & 0.9 & 3.132 .20 \\
Germany & 76.79 & 41.63 & 1.3 & 4.03 .50 \\
Finland & 74.32 & 41.81 & 1.1 & 2.83 .35 \\
Portugal & 85.1 & 29.38 & 1.4 & 3.53 .90 \\
\hline
\end{tabular}

Source: Eurostat (2012), OECD (2008), Calculations of DIW Berlin.

Product market regulation: The OECD Indicators of Product Market Regulation (PMR) are a comprehensive and internationally-comparable set of indicators that measure the degree to which policies promote or inhibit competition in areas of the product market where competition is viable. The indicators cover formal regulations in the following areas: state control of business enterprises; legal and administrative barriers to entrepreneurship; barriers to international trade and investment.

Barriers to entry in services: sub-indicator of product market regulation, includes professional services: Licensing, Education requirements and Retail trade: licenses or permits needed to engage in commercial activity, specific regulation of large outlet, protection of existing firms.

One reason for the deficits in the economic structure of Greece lies in the highly inefficient and corrupt public administration, the target of the further planned institutional reforms. The OECD (2010) provides composite indicators of product market regulations and of barriers to business entry (see Table 4). Both indicators reflect the numerous regulations, bureaucratic hurdles and restrictions that Greek entrepreneurs face. Greece is one of the most regulated economies in the EU (see OECD 2010) and each decision to enter the market bears a substantial risk of failure because bureaucratic hurdles can be insurmountable for entrepreneurs. ${ }^{7}$ In this vein, estimates show that bureaucracy costs about 6.8 percent of GDP in Greece, while the EU average is 3.5 percent (see Drymiotis 2012) (Figure 4).

This leads to the last crucial issue: Corruption, the other side of the coin of overregulation, is part of everyday life, like the bribery of bureaucrats, tax collectors, and judges. Whenever a decision is needed or an absurdly high penalty could be enforced, corruption prevails. Greece is considered to be the most corrupt Euro-zone country (Figure 4). This corruption is not just detrimental to the economy in general, but specifically to innovation and entrepreneurship. Corruption is one reason why researchers and innovators stay away or leave. Recent investigations cannot find evidence of changes in the level of corruption. ${ }^{8}$

In a nutshell: the analysis makes clear that Greece does not have a cost problem, but fundamental institutional and structural problems. Cutting costs will make Greece more competitive, but at a wage level below European standards. If only the doubtlessly necessary institutional reforms are made, Greece will follow a path of limited growth in sectors of low added value. Tourism, agriculture and trade are not enough to create sustainable, growing wealth for the whole country. If Greece is to make growth progress within the group of Euro-zone countries, it must move beyond institutional reforms. As we argue, it needs to focus on policy measures that support an innovation driven economy in combination with the necessary institutional reforms. As we will show, there exists a base for such a model. 


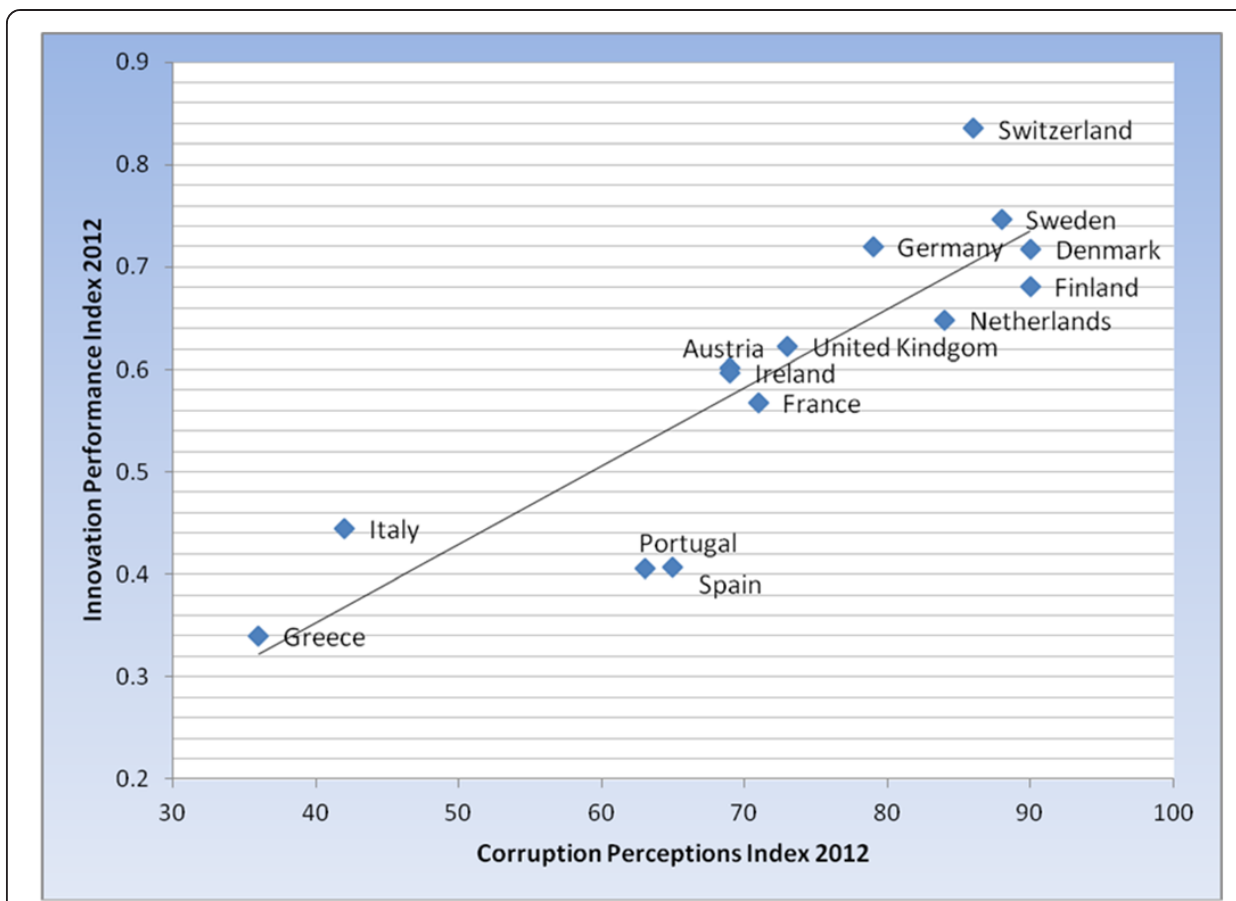

Figure 4 Innovation performance and corruption. Note: A higher corruption perception index corresponds to a lower level of corruption in a given country. Source: Innovation Union Scoreboard (2012), Transparency International (2012).

\section{Innovation: Why and How to support - brains and the right innovation environment}

\subsection{Innovative firms and entrepreneurs as the main drivers of growth}

Tourism will remain an important part of Greece's economy. However, if Greece aims to create long-term sustainable wealth, it must build additional industries with high added value. Ample research demonstrates why it is worth developing an innovation friendly environment with support for innovative firms. Aghion and Howitt (1992), for instance, focus on such firms and, using an endogenous growth approach with the Schumpeterian theory of "creative destruction", find that innovative firms are at the center of sustainable economic growth. As Baumol and Schilling (2008, p.1), put it "innovative entrepreneurs do make a substantial difference to a nation's growth rate, having introduced many breakthrough innovations".

From the analysis of innovation chains, we know that an economy needs an upstream innovation system (Nelson 1993) in order to be able to initiate entrepreneurial activities on a broader basis with innovative and productive firms. Essentially, an innovation chain starts with excellent basic research, with flowing transitions to publicly financed applied research. The research and development activities of private companies yield stepwise spillovers from ideas to innovative products, which need proof of concept, market demonstrations and commercialization (Gilbert et al., 2008). Moreover, just building publicly and privately financed research institutions is not sufficient. On the one hand, the development of new ideas and innovative activities require, as Nelson and Wright (1992) emphasize, the exchange and interaction of all players in such an innovation chain beyond those acting in firms. Further ingredients are social structures 
and soft factors - like mutual trust and common commitment to decency - that support innovative actions in such an interdependent system (Callon 1991). Freeman (1987, p. 1) defines these interdependent systems as "networks of institutions in the public and private sector whose activities and interactions initiate and diffuse new technologies." On the other hand, spillovers of new ideas to innovative products coming along with the venturing of businesses need a regulatory environment that protects ideas and allows an easy entry of new firms into the market. If these ingredients for innovative actions are mixed in the right way, the long-term commitment to research and innovation will pay off with growth, higher incomes and prosperity (Cho and Pucik, 2005; Wong, et al., 2005).

\subsection{Ingredients of innovation and an innovation friendly environment}

Several factors are required to design the transformation to an innovation-driven economy. Beyond any institutional settings, an economy needs three kind of talented people: individuals conducting high class research along the innovation chain, entrepreneurs endowed with the right traits and skills able to be creative and innovative while bearing the uncertainty connected with the innovation of new products (Knight 1921; Caliendo, et al., 2011), and managers able to make the transition of innovative prototypes to marketable products.

To attract, train and retain talented people and to give researchers, entrepreneurs and managers a fitting structure enabling them to make their specific contributions within the innovation chain, economies need appropriately developed innovation systems (Nelson 1993). These consist of high quality schools and universities, as well as professional education systems and excellent research within the public sector. It further needs a functioning financial sector, informal and formal institutions, non-exploitative networks, as well as a suitable regulatory environment that facilitates internal markets open to new products and international competition. We elaborate in this section why these factors are important for an innovative economy. We will sort them into systemic factors; such as education, research and development, and institutional factors.

Among the systemic factors, high quality schools, universities and professional education are an indispensable input factor to attract and train the people necessary for innovation: researchers, entrepreneurs and managers. A well-developed educational system influences the innovation capacity by increasing the level of human capital in a country or, more specifically, the aggregated knowledge, skills, and abilities of the human beings that ultimately become innovative (Gennaioli et al., 2012). The investment into the education of individuals is, therefore, critical to build an innovation economy (Baumol 2005).

There is no innovation without public and private research (Ames, 1961). Public research is critical and cannot be substituted with private research (see Mazzucato 2011). Often, public research activities are divided between basic research (aiming to increase the understanding of fundamental principles) and applied research (aiming to yield practical benefits or technical solutions to specific problems with the target of commercial use). These different research activities along the innovation chain are usually conducted in different kind of research institutions, often connected by translational research that aims to further develop basic research toward its application. The quantity and quality of such research activities depend on the research and development (R\&D) funds available and on the excellence of the researchers using the funds. The principle of meritocracy is of fundamental importance for attracting productive researchers into the public sector (Ariu and Squicciarini, 2013). 
As the success of the US and Switzerland suggest, focusing on fewer, but outstanding researchers in the public domain produces greater returns on public investments. Also the administrative burden underlying the use of these funds is a factor creating obstacles (Cullmann et al. 2012).

Given the great variety of research areas, the establishment and development of research institutions should be carefully planned. The clustering of different institutions to build up a critical mass of talent in the same location allows for more productive research along the lines of the innovation chain (Bettencourt et al., 2007). Spill-overs to entrepreneurs and spin-offs out of research institutes will also generate innovative products with a higher probability if high-tech start-ups also locate in the same area. Examples like Silicon Valley, or recently in Berlin-Adlershof or Tel Aviv, provide role models of well-functioning clusters. In these clusters, networks are created between players along the innovation chain, in particular between public researchers and private entrepreneurs striving for innovation, which are key for an economy aiming for innovative products. Through interaction and cooperation within a network, innovation processes can be accelerated (Porter 1998). Given the specialization of each network member, scarce resources can be used more efficiently and may increase the speed and probability of successful innovations. However, as the character of new ideas as subjects of commercial exchange is peculiar (see Arrow's (1971, p. 152) information paradox on the difficulty of enforcing the property rights of ideas), in order to be powerful, such networks need a high level of trust. For trust to emerge and be sustained, it needs in turn informal institutions that enforce cooperative and fair behavior. Hence the absence or presence of the right informal institutions is a decisive factor for the success of networks creating innovations.

If an innovation chain is established by appropriately collocated research institutes being also well connected through networks, and if entrepreneurs are able to transfer ideas or prototypes to marketable products, they will need capital. In particular, the availability of risk bearing financial funds is the next prerequisite for starting innovative businesses. Even if entrepreneurs try to finance their projects with internal funds, such as personal wealth or money provided by friends and family, a large number of innovative start-ups face equity gaps (see Veugelers 2011). Banks, and even more so, venture capitalists are the most important financial intermediaries providing funds to business start-ups. Due to their specialization, they allocate funds to small firms most efficiently (Diamond 1991).

The last link in the innovation chain relates to the implementation and commercialization of new products and services in the country of origin. Translating the outcomes of research into marketable products produced, implemented and sold in the country where they were invented, strengthens the positioning of innovators and encourages them to stay in the country of origin. Commercialization is, thus, the last step that needs realization and it needs managerial capacities able to handle the challenges of introducing new products to a market.

However, invention will remain without almost any introduction of new products in the markets if entrepreneurs face a regulatory environment being adverse to the venturing of new businesses and the protection of property rights. It is, therefore, a necessary condition to focus on those institutions that are decisive in determining whether or not the environment for innovation is friendly, in particular on those institutions that secure property rights, enforce commercial laws, improve general business climate and further reduce regulatory burdens. 
Government policies and legislation with regard to intellectual property rights are important in shaping a country's innovativeness. A property right is the right to own something, thus, a prerequisite to own wealth (Fisher 2007). Therefore granting property rights ensures that the corresponding wealth stays with the entrepreneur. Without property rights the incentives to be entrepreneurial and to create something new do not exist because there may be no reward for working on it. Lack of protection of ideas will generally lead to fewer investments in innovation and thereby hinder entrepreneurship (see Anderson, 2003).

Commercial law is important in supporting entrepreneurship and innovation as well. Complex regulations make it difficult to understand the legal circumstances for any investment. An important step, therefore, is the comprehensive codification of legislation. Moreover, requirements for setting up a business, like buying a license from an existing license owner and other manifold entry barriers, may discourage individuals from becoming an entrepreneur as well (Kloosterman 2003). Overregulation of commerce prevents productive entrepreneurship from flourishing because it increases the cost of starting a business, reduces flexibility and the possibility to act quickly on developing opportunities, as well as reducing experimentation (Gruenhagen and Berg, 2011). The ability for experimentation is a crucially important component for entrepreneurs. The opportunities needed for experimentation will be greater in deregulated economies with free market mechanisms because entrepreneurs can be flexible in their approach and develop new entrepreneurial activities (Gnyawali and Fogel, 1994). Of course, it is as important that these laws are actually enforced (Levie and Autio, 2011).

The other side of the coin of regulation, the issue of corruption, must also be addressed. The level of corruption has negative impacts on innovative activities in a country. Innovation is about new products where success in the markets is uncertain. If this uncertainty is increased by uncertainty on property rights due to a corrupt law enforcement system, the total uncertainty can become prohibitively high. As Audretsch and Feldman (1996) further put it, corruption may affect the willingness of entrepreneurs to trust the surrounding institutions, which are necessary to protect intellectual property rights, and networks, who jointly work (as mentioned before) on intellectual property rights creation. Trustful entrepreneurs in such an environment risk losing access to the entitled profits of their innovative ideas when opportunistic players take advantage of their created value added (Anokhin and Schulze, 2009). Apart from the issue of lack of trust and too much uncertainty on property rights, corrupt environments also impose costs on the innovator, as many innovations are about a "Winner-takes it all game". Being the first is crucial to make the return on innovation profitable. In this "rat race" the loss of time and money (in case the innovator being ready to bribe) invested into corrupt structures can mean that players lose the race. As innovators are welcomed all over the world, locations with corrupt administration will fail to attract innovative brains.

Putting together the puzzle, it is crucial for any economy aiming to create a business climate conducive to entrepreneurship to adjust its institutional system. This means it must reduce regulatory burdens ensuring the right conditions prevail for an environment open for innovation, and to invest in the development of its innovation system as described here. If these steps are done correctly, entrepreneurs are able to transfer new ideas into marketable products in their home country and not abroad. The problem remains that all systemic and institutional factors need to be in place in order to allow 
innovations to evolve efficiently. If any single factor is missing, innovation will occur more slowly than is possible. This dilemma mirrors literature on "innovation systems," referring to the factors limiting the effects of an innovation driven economy.

\subsection{Greece's Way to the future: current environment and hidden assets}

Looking at Greece of today, at first glance the preconditions for an innovation economy appear to be suboptimal, with only small parts of an innovation system being in place. A comparison, as presented in the EU industrial innovation scoreboard, finds Greece in 20th place out of the EU 27, close to Hungary. This performance is no surprise. Information on investments in research and development (R\&D) - as a first measure of the innovative efforts in the Greek economy (see Figure 5) - reveals that related to the annual GDP, Greece spends 0.5 percent on R\&D activities (with a focus on the IT sector), less than any other Eurozone economy and closer to countries like Egypt than to the EU average. In addition, private R\&D investments make up less than $0.2 \%$ of GDP. Sweden, at the other end of the scale, allocates 3 percent of GDP to private R\&D. Research networks barely exist in Greece and collaboration with industry is poor. Moreover, there is no financial basis for funding innovative investments: As holders of Greek government bonds, banks are currently undercapitalized and venture capital is virtually non-existent. And it is a well-known fact that Greek private investors, potential sponsors of innovative investments, have parked their funds outside of Greece or even outside the Euro-zone (Evans-Pritchard 2012). At the end of the innovation chain, when it comes to abilities of handing launches of new products, Greece again finds herself at the bottom of rankings on management practice scores (see Bloom et al., 2012).

The regulatory environment for innovation is in a bad shape as well, most probably also explaining why private investors stay away from Greece. Greece has an overregulated legal framework that puts substantial burdens and lengthy procedures on its entrepreneurs and business owners regarding entry regulations, property registration and obtaining or extending licenses or permits, as well as reporting duties, as measured by the World Bank (2012) indicator. In 2010, Greece ranked 109th out of 183 countries, far below any other

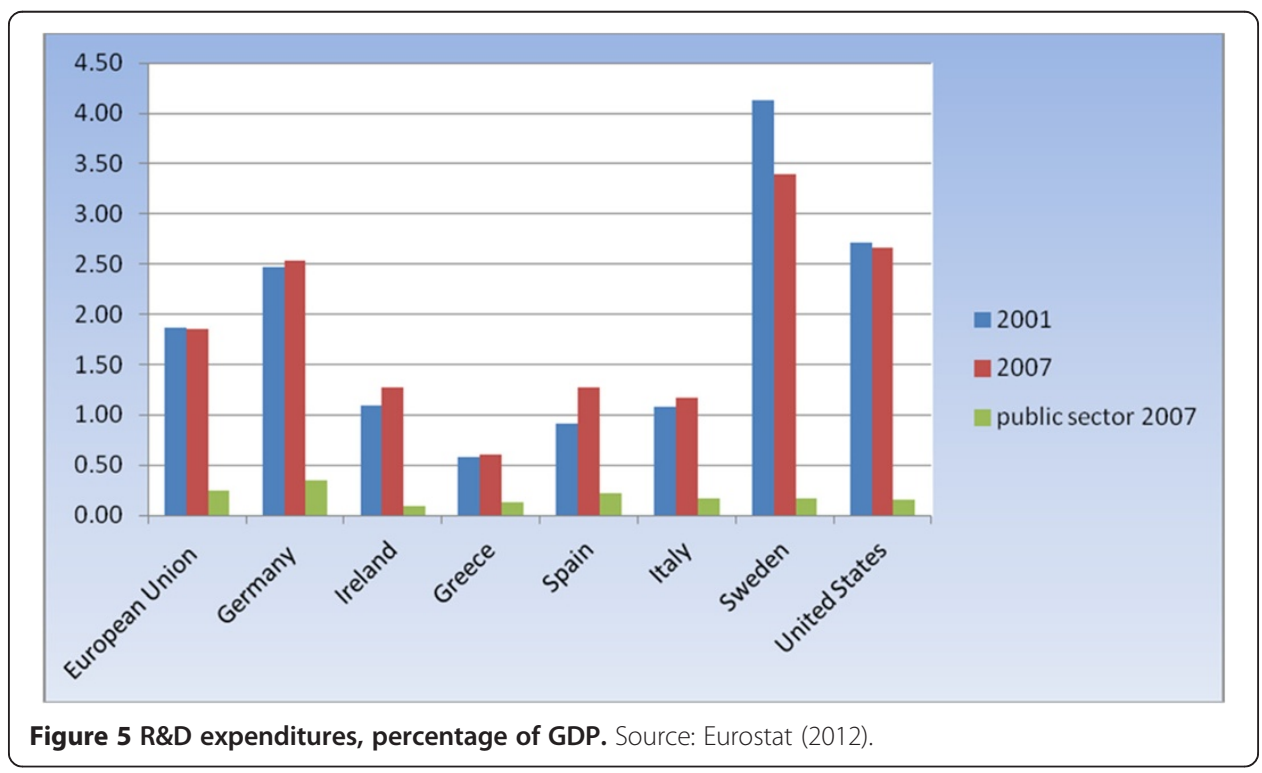


Euro-zone economy (with Italy the second lowest at 78th). As the European Commissio $(2010,43)$ puts it, "the business environment also suffers from obstacles to starting a business, the little protection given to investors and the difficulty to access finance".

Overall this picture does not seem encouraging for the vision of an innovation driven Greek economy. However, one has to acknowledge initial improvements over the past year and many of the hidden assets of Greece have been substantially underappreciated in the analysis of Greece's economic prospects. The first asset is the small number of mostly basic research institutes that produce considerable research output (see also Grant et al. 2011). This is substantiated through the number of ERC grants (the most competitive funding scheme in Europe for outstanding researchers) as a proxy for research excellence. A second hidden asset is that more Greek ERC recipients are working at institutions outside of Greece, in other European Member States (see Figure 6), than in Greece. This data omits Greek scientists working at institutions outside the EU. When comparing Greece with other European countries, Greece is found to be the only country "exporting" more top scientists to other European countries than it is able to keep at home; this does not count for the fact that Greece does not readily attract foreign scientists. However, averaging Greek researchers (in Greece and in Europe) over the Greek population shows that the ratio of grants to the population is similar to innovation economies like France, Germany, or Great Britain and better than the ratio for Spanish researchers (see Table 5). If this "brain power" could be unleashed within Greece, the country could turn more quickly into an innovation economy.

Third, initial steps toward developing research clusters have been made; for instance by the Demokritos research institute (see Kanellopoulos 2012). Moreover, there is a considerable number of small, but innovative companies all over Greece that have developed new ideas that are on the cusp of being turned into marketable products (see Tsiros 2011). These firms have remained in Greece despite the adverse innovation environment.

This brings us to the fourth and final "hidden asset" of Greece: Its attractiveness in terms of climate and quality of life. In an increasingly global race for the best talents, life quality outside labs turns into a crucial success factor. Labs, researchers, patent

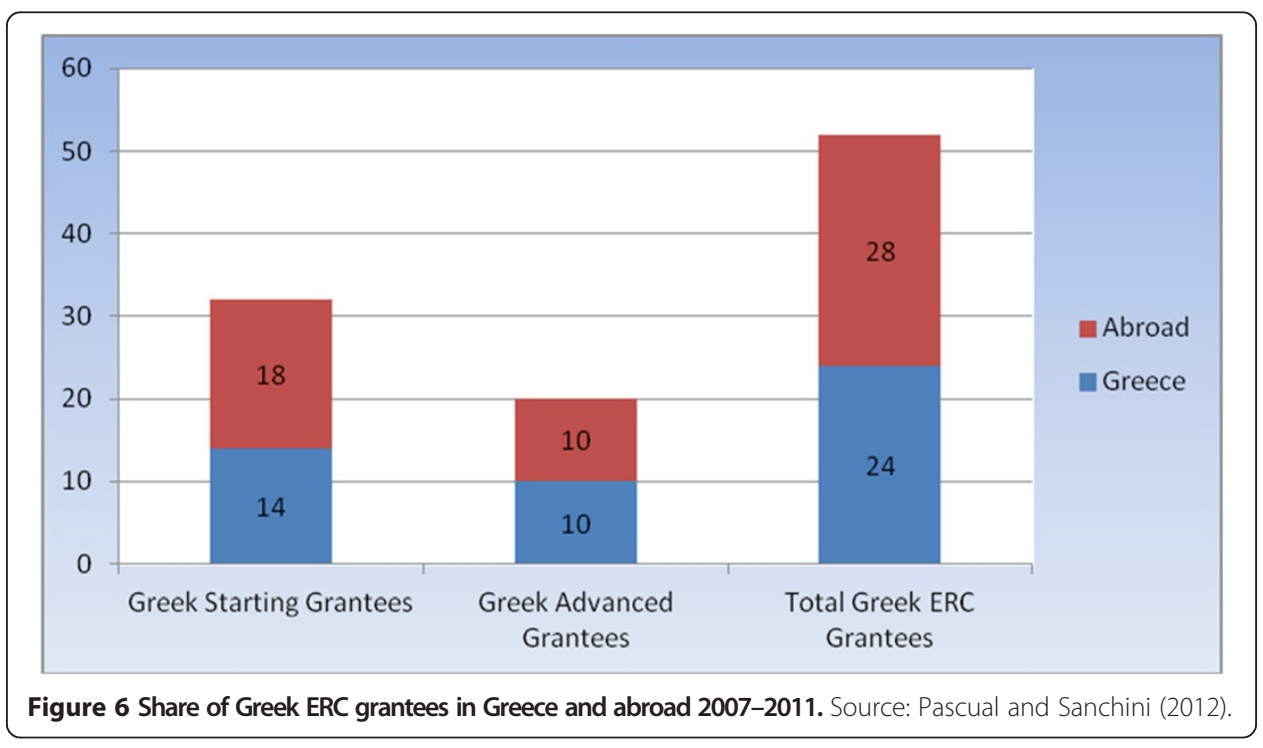


Table 5 Distribution of ERC Grants, home and abroad, and related to population

\begin{tabular}{lccccc}
\hline & $\begin{array}{c}\text { Population in } \\
\text { Millions (2011) }\end{array}$ & $\begin{array}{c}\text { ERC Grants home } \\
\mathbf{2 0 0 7 - 2 0 1 1}\end{array}$ & $\begin{array}{c}\text { ERC Grants } \\
\text { abroad 2007 - 2011 }\end{array}$ & $\begin{array}{c}\text { Total ERC Grants } \\
\text { (2007 - 2011) }\end{array}$ & $\begin{array}{c}\text { Share over } \\
\text { population }\end{array}$ \\
\hline Greece & 10.5 & 24 & 28 & 52 & 5.0 \\
Germany & 81.8 & 250 & 150 & 400 & 4.9 \\
Finland & 5,4 & 35 & 6 & 41 & 7.6 \\
Spain & 46.1 & 100 & 30 & 130 & 2.8 \\
France & 65.0 & 240 & 50 & 290 & 4.5 \\
Italy & 60.6 & 145 & 100 & 245 & 4.0 \\
United & 62.5 & 310 & 40 & 350 & 5.6 \\
Kingdom & & & & & \\
\hline
\end{tabular}

Source: European Research Concil (2012): Supporting Top Researchers from Anywhere in the World, http://erc.europa.eu/ statistics-0. Eurostat (2012), Calculations of DIW Berlin.

lawyers and venture capital can move easily, while climate, landscape and historical heritage cannot. Some outstanding research universities in northern Europe and the northern US have already experienced the problem of competing against universities in places of higher quality of life, like California, Australia, Singapore and Israel. Europe so far does not dispose of a "global attractor" where world-class academic research is matched by locations with attractive climate and quality of life. In this respect Greece has a unique comparative advantage to most EU members and could make a significant contribution to Europe's collective problem of lacking the combination of places with internationally competitive employment conditions (Halme et al., 2012) and attractive life quality. If quality of life is matched with excellent research and public administration, Greece could become Europe's global attractor for talents (Figure 7).

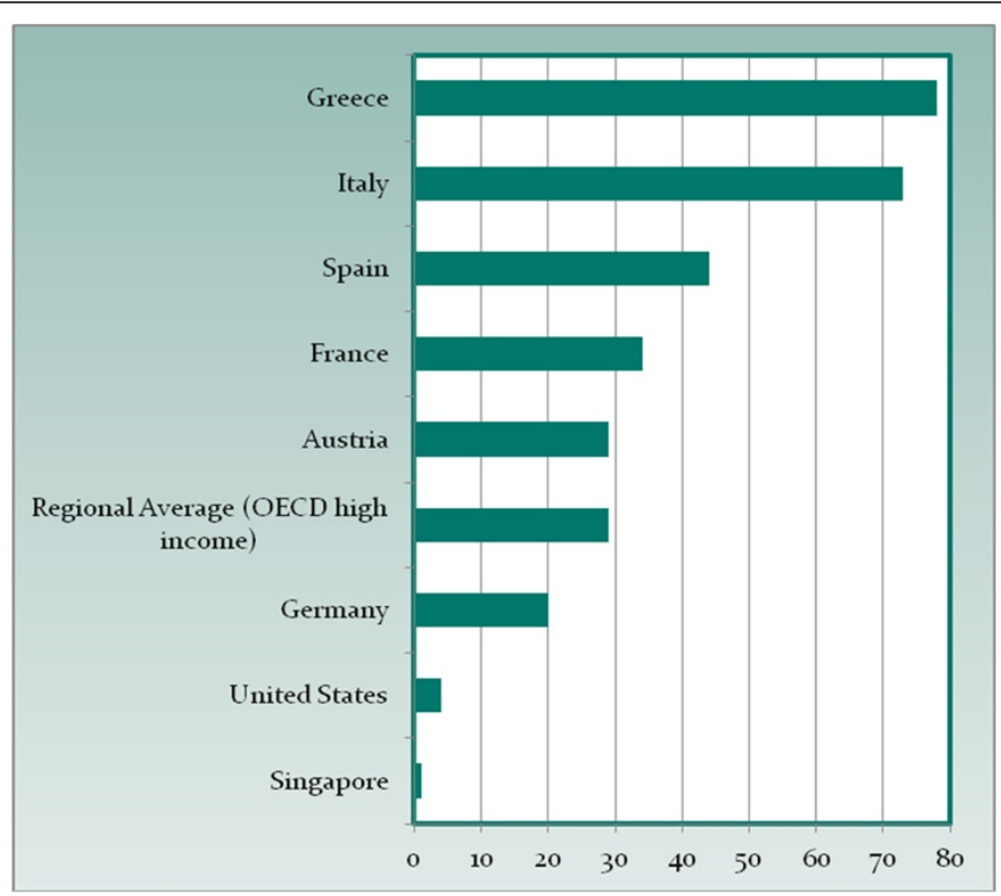

Figure 7 Ease of doing business 2012. The Figure indicates the rank of select countries in the indicator of the World Bank. Greece is currently placed at rank 78, Singapore at rank 1. Source: The World Bank (2012), http://www.doingbusiness.org/rankings. 
With respect to the business climate, the World Bank reports incremental improvements. In their study on "doing business", the Greece's indicator rose to 78th in 2013. Improvements were noted for "protecting investors", "paying taxes", "trading across borders", and for "resolving insolvency" (see Figure 7). No improvements were so far reported and positions are still far below average with respect to "starting a business" (ranked 146th), "registering property" (ranked 150th), and "enforcing contracts" (ranked 78th). The same holds true for corruption. As mentioned in Section 2, according to Transparency International there are no changes in Greece that have reduced corrupt activities. An efficient set of commercial laws is, however, crucial to promote entrepreneurship and innovation, not only for introducing existing innovations in the Greek economic fabric, but also with respect to foreign direct investment. International investors, as one critical indicator for the openness and innovative environment of a country, may otherwise still shy away from Greece and will allocate their money to other countries where their investment is better protected (Luthans et al., 2000).

Thus, drawing these arguments together, there is a well-established understanding of what is required at the beginning of the innovation chain. However, given the high regulatory burden and the unfriendly environment toward innovative companies in Greece, there are only a scattered number of high-tech start-ups and no knowledge transferring institutions or applied research between the existing basic research institutes and the later exploitation of their fundamental findings. And instead of networks between researchers, institutes work rather in an isolated way with the majority of their top researchers leaving the country.

\section{Toward a Greek silicon valley}

\subsection{Innovation or just tourism: the example of Orlando versus San josé}

Obviously the Greek leaders and society face a choice of how to turn their assets, in particular the quality of life, into economic activity: They can either support the tourist industry only, by allowing in fast procedures that unused land is further transformed to new hotels, or they can use these same assets to lay the groundwork for attracting creative, talented and ambitious knowledge workers from over the world. The first strategy might earn additional returns in the short-term, but will have limited long-term impact on the economic performance of Greece. The second strategy will need more time to produce returns, but these returns are more likely to increase over the long run, which if applied ambitiously could transform Greece into the leading innovation economy in southeast Europe.

Looking at the economic long-term impact of regions that successfully went through this transformation process might encourage Greek decision makers toward such a commitment. This may hold despite all insider-outsider problems, which makes the current system attractive to insiders (see Vassilatos et al., 2012). Although the high regulatory burden especially protects insiders, we argue that even insiders will benefit financially under an innovation economy. If we take house prices as a proxy for relative wealth, one can see that US cities that are innovation centers have real estate prices well above the US average. An extreme example is San José (Silicon Valley), where median house prices in 2010 were almost four times the US average (Figure 8).

A closer look at the outcomes exemplifying these two strategies in the US provides insights on the most profitable approach for Greece. Orlando, Florida, is a tourist 


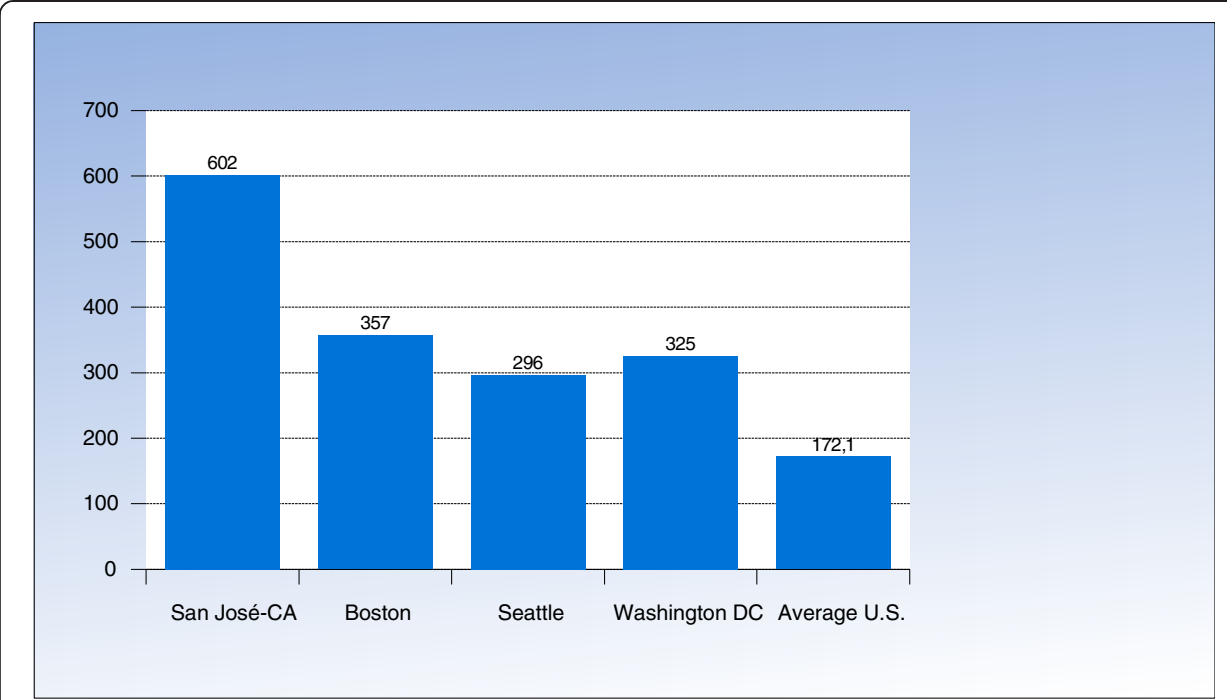

Figure 8 Median Home Prices of various cities in the US. Source: Silicon Valley Information and Communications Technologies Study (2011), http://www.netvalley.com/silicon_valley_history.htm.

magnet, and best models the tourism-based approach. In contrast, San José, the "capital of Silicon Valley", hosts some of the world's best institutions of higher education and research. The graphical presentation of price development in these two regions shows a massive difference in wealth between Orlando and San José (Figure 9 and Table 6). The median of real-estate prices has been much higher in San José than in Orlando over the last decade. If we compare the price levels at the peak of the real estate boom, we find the median of property prices in San José is more than twice $(669,000$ USD) the median in Orlando (255,000 USD). This differential became more impressive in the course of the crisis: In the last quarter of 2011 (Figure 9), the median of property prices in San José being more than four times the price level in Orlando.

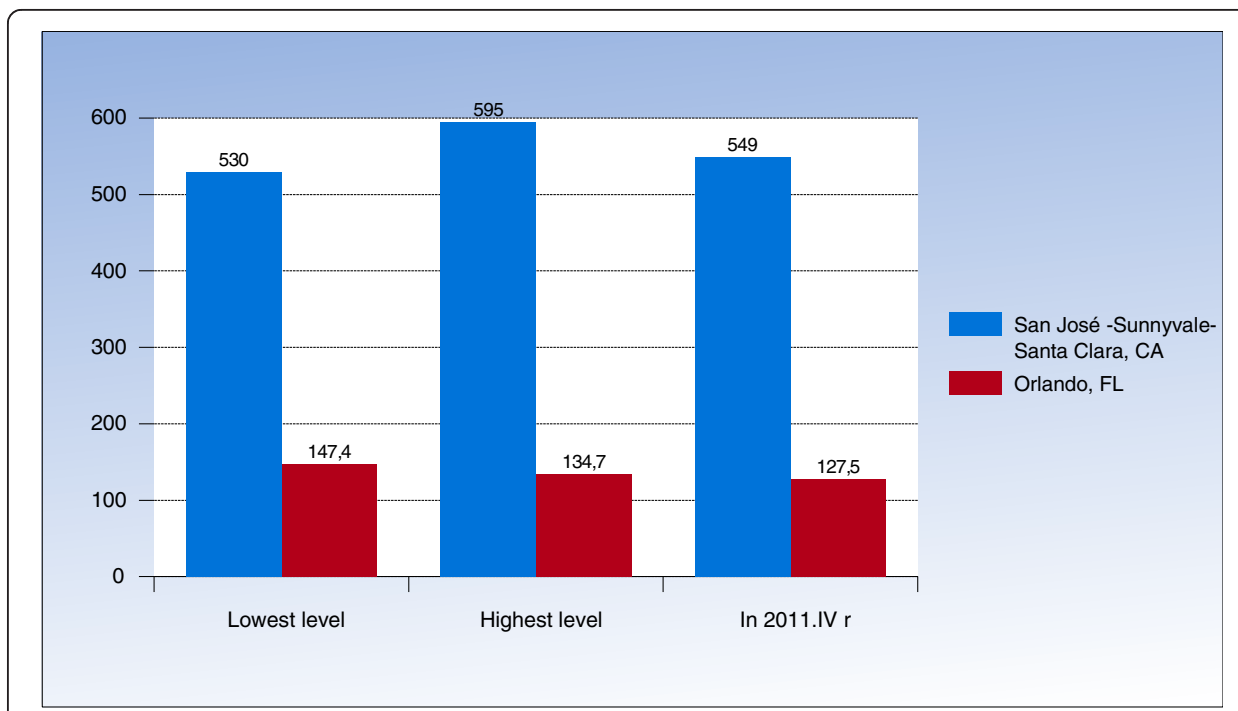

Figure 9 Median sales price (all properties) - comparison in the period 2000-2011. Source: National Association of REALTORS and Trulia.com. 
Table 6 Median sales price of existing single-family homes for metropolitan areas

\begin{tabular}{lllllllll}
\hline & $\mathbf{2 0 0 9}$ & $\mathbf{2 0 1 0}$ & $\mathbf{2 0 1 1} \mathbf{~ r}$ & $\mathbf{2 0 1 1 . I}$ & $\mathbf{2 0 1 1 . I I}$ & $\mathbf{2 0 1 1 . I I I}$ & $\mathbf{2 0 1 1 . I V ~} \mathbf{~ 2 0 1 2 . I ~ p}$ \\
\hline San José -Sunnyvale-Santa Clara, CA & 530.0 & 595.0 & 570.0 & 535.0 & 600.0 & 587.5 & 549.0 & 535.5 \\
Orlando, FL & 147.4 & 134.7 & 124.9 & 119.7 & 125.6 & 128.3 & 127.5 & 124.6 \\
U.S & 172.1 & 173.1 & 166.2 & 158.7 & 169.1 & 173.0 & 162.6 & 158.1 \\
\hline
\end{tabular}

Source: National Association of REALTORS 2012.

Doubtless this comparison of median of property prices in San José and Orlando only conveys a rough measure of tourism versus high-tech industry based economies. However, the dramatic difference in property prices is an indicator that, for a region blessed by attractiveness in quality of life, investments in outstanding higher education and in world-class public research, this can be a more effective strategy than the tourist industry alone. Turning to Greece, tourism might provide short-term revenues in land sales along the tiny slice of land along the coastline, and small long-term revenues in the service industry as real estate is maintained and tourists entertained. Tourism might be the right choice for the Greek islands, but mainland Greece and large islands, in particular Crete, might be better advised to go for the "San José approach". It will have the chance to transform more than the tiny slice of coastline into high priced land - Athens, as well as other Greek cities and regions, could see real estate prices soar. At the same time, the San José approach will produce long-term (tax) revenues in terms of well-paid jobs in new industries.

\subsection{A Ten point policy plan to realize a Greek vision of an innovation Hub}

If Greek authorities decide to capitalize their unique asset of land and life quality in the fashion of San José, they will find their country headed toward economic growth. Other examples of surprising emergence of new centers of high-tech innovation, like Tel Aviv and Berlin, should encourage the Greek government to follow this model. On the road to San José, the Greek government must make critical decisions. A good starting point is that Greece does not have to build an innovation system from scratch, but can rely on existing research institutes and entrepreneurs willing to venture innovative firms. What they need is the gaps in the innovation chain closed; in particular by providing high quality education and professional training as well as publically funded research in a few, excellent universities and research centers, with orientation toward applied research. Further, institutions which create networks and clusters, protect (intellectual) property rights, and streamline bureaucracy will allow Greek entrepreneurs to introduce new marketable products or processes in Greece instead of in other countries.

A significant number of additional reforms need to be implemented in order to create the necessary research structure and innovation friendly environment. Moreover, these reforms and policy changes while being in the responsibility of the Greek government, need to be supported and endorsed by investors, company owners, and Greek citizens. Based on the components of an innovation chain and the current situation in Greece, we recommend several policy measures designed to stimulate innovation in Greece. Related to the systemic and institutional factors described in Section 3.2, and the status quo of these factors in Greece described in Sections 3.3, the following 10 point policy plan is recommended: 
1. The development of existing and establishment of new research institutes and research universities of the highest quality: Closing the gaps of the innovation chain need to be the first aim of the government. Given the specialization of the existing research institutes and universities, the research capacities need to be extended with a strong focus on creating spatially bounded knowledge spillover. Given that such a strategy needs a strong increase of public investments and given the current state of the Greek national budget, the European Commission provides in the Research Framework Programme Horizon 2020 two new tools that will help Greece to attract the top of research excellence: ERA Chairs and "Teaming excellence" (see Laursen, 2012). With the ERA-chairs-programme, the EU offers a funding instrument for universities and public research institutes in convergence regions like Greece designed to attract outstanding researchers from abroad for longer stays. The larger "teaming excellence" instrument will supply financial support for the establishment of a branch institute of an excellent research institution in a transition region. Teams of research institutions, like Cambridge University, and transition regions, like the city of Thessaloniki, can make a joint proposal under this framework. This instrument provides Greek regions the opportunity to leapfrog to the top of Europe's research performance: With new Greek research institutes carrying the reputation of meritocracy and excellent administration of Europe's research institutions, the country will better attract the research talents.

Ideally, the competition for ERA chairs and new "teaming for excellence institutes" is accompanied by a restructuring of the public research system: An evaluation based on measuring performance in terms of internationally recognized publications and patents would facilitate the reallocation of unproductive research groups to academic teaching, leaving the scarce resources to the most productive researchers. The Structural funds could be used to provide infrastructure to highly productive researchers. If wisely combined, the Structural funds together with the two new European programs will enable Greece to create research institutes and universities of the highest quality.

2. Provide incentives for researchers to stay in Greece: The most important resources for generating an innovation economy are the researchers working for it. Well-educated researchers are the driving force behind cutting edge research, new developments, and innovation. Well-educated Greek researchers currently work at institutions in the US and across Europe. In order to be able to compete with research institutions elsewhere in the world, Greek stakeholders must remove the barriers that discourage Greek researchers from staying home and other researchers from coming to Greece. Thus, working and research conditions have to be designed appropriately to stop the brain drain. Attractive conditions contain three aspects: (a) independent research with the only target of top quality research output; (b) salaries that compete with similar institutions in Europe; and (c) a low regulatory burden for starting research in Greece.

3. Expanding research clusters and networks based on existing specialization: Once the public research system in Greece is put on the track toward excellence, it will be important to plan the creation of new research institutes in research areas with a given Greek specialization. Moreover, research shows (see e.g. Ellison and 
Glaeser, 1999) that clusters will be particularly successful in terms of knowledge spillovers when research institutes, universities and innovative companies are geographically concentrated. An impressive example of how education and research can turn into new innovation based economic growth is the recent of "Berlin Adlershof". After Berlin became a center of exceptional education (hosting an "excellence university" and research with about one dozen federal research institutes of the Fraunhofer, Leibniz and Max Planck societies), the newly established "Berlin-Adlershof" technology-park became home for 1,000 companies, including more than 400 high-tech start-ups (for more details see WISTA 2011) that received seed finance from specially designed public funds. With similar injections of research and academic input, Greece could also emulate the story of "Berlin Adlershof". In this context the Greek government has to rethink the geographical reallocation of its scattered research institutes. Furthermore, the technology park infrastructure, built in the past with the help of Structural Funds from the European Union, should be re-activated. In the presence of outstanding research and education, basic technology park infrastructure can turn into hubs of innovation.

4. Risk Capital for Start-ups: Once knowledge spillovers are turned to new products, it is necessary to close the equity gap of the high-tech start-ups. Access to risk capital will then be one major requirement for a vibrant entrepreneurial culture in Greece. Where necessary, standards and regulations for the provision of seed and equity capital should be adjusted so that venture capital is attracted to Greece, on the one hand (see Bygrave and Timmons, 1992), while seed capital needs to be provided from public sources, on the other. Most importantly, venture capital will be attracted if research centers of excellence are established, research clusters are developed, and top researchers are attracted.

5. Reform of the education system and strengthening of professional training: Parallel to the research approach, there is also need for an excellent professional training system to get ideas and discoveries turned into new products and services produced in Greece. Currently new ideas cannot easily make it to the market not just because of the bureaucratic hurdles but also because practical skills are missing from the Greek labor market. Such skills are not valued in the Greek society. There is great potential in this area if Greece takes inspiration from the Swiss system of professional education. The existing technical colleges in Greece (particularly those run by the OAED, the public employment agency) provide the basis to build on a public-private-partnership in education that can lead to significant increases in the quality of professional education at almost zero cost to the public sector. On top of that, the European Social Funds or the Leonardo da Vinci Programme could be used to give young people with talent in practical skills the opportunity to learn cutting edge knowledge in their field of profession abroad. Furthermore Greece is home to the European Centre for the Development of Vocational Training providing unique professional training expertise. No other EU - Member State has such easy access to best practice.

6. Improve regulations for (innovative) enterprises and implement reforms: As of 2012, according to the World Bank (2012) report, regulations are still very high for new firms in Greece, hindering or imposing substantial cost to both innovators 
and researchers who are seeking to commercialize their invention through new business ventures. Administrative efforts for start-up activities need to be substantially reduced. This should include reducing the number of days needed to register new businesses, the number of bureaucratic steps involved in this process, as well as the number of regulations, fees and reporting duties. As a benchmark, Greece should aim to realize permanent business registration within one day. To become a fast and efficient public administration, Greece must implement state of the art e-administration for all businesses, (e.g. registering online new businesses, tax declaration, each within one hour). Instead of relaxing on its improvement from the $109^{\text {th }}$ to $78^{\text {th }}$ place, Greece needs to become one of World Bank's top 20 when it comes to "Ease of doing business", as a couple of EU-countries recently succeeded to do. Moreover, all reforms already approved by legislation (mentioned before) and those reforms that still need to pass parliament will only become effective once implemented and enforced by courts. To support the necessary adjustment processes, administrative officials need to be appropriately trained.

7. Codification and simplification of legislation: In a similar vein, conflicting legislation also creates uncertainty and additional costs for businesses. Codification means bringing all amendments to a given law, adopted at different times, into one law. A swift and comprehensive codification of Greek legislation will eliminate contradictions and simplify administrative legislation. This should include the reduction and unification of the number of administrative procedures relating to any single activity (for details see the EU efforts on "better regulation", EU-Commission 2009).

8. Further refinement of the Kallikratis-Tax reform: For successful innovation economies, municipal leaders committed to create an excellent local business climate (efficient, fast administration, excellent primary and secondary education, and good health services) are essential as they create "hands on" the right environment for innovative entrepreneurs. In most successful innovation economies, municipalities are therefore entitled to a share of the locally produced tax-income, rewarding their efforts to create an attractive business environment. Greek municipality leaders are excluded from business revenues produced in their municipality, reducing thereby their interest in caring for the local business climate. Greek municipality leaders will transform to active advocates of excellent business climate when municipalities get a significant share of tax revenues from business activities in their municipalities (collection of taxes still subject to central authority). A share in property tax would not be enough as this provides only the incentive to local politicians to waste land (e.g. for cheap tourism), rather than taking care for sustainable economic growth at local level. A local occupational or business tax would instead create the feedback-control for good local business climate. The second best solution would be a direct share in income tax (not like currently - getting a share of the central pool income tax according to a fixed formula). Such reforms of tax-reassignment (while keeping collection of taxes still to central authorities) would deliver a fundamental change in speed of the transition of Greece to an innovation based economy.

9. Start-up Grants: With the impending downsizing of the public administration, a new pool of entrepreneurial talent will be forced to seek their fortunes. To give 
incentives to the unemployed for starting a business, entrepreneurial activities should be rewarded with grants that cover the basic cost of living during the first six months of start-up. The overall goal of such an instrument is to increase the survival probability of entrepreneurs when their freshly created businesses are still vulnerable (for details on how to design start-up grants without creating windfall profits, see Caliendo and Kritikos, 2010).

10. Diaspora policy: Almost all measures discussed so far aiming to close the innovation chain gaps can be supported with a target-oriented Diaspora policy. Currently, the Greek Diaspora, although very strong, is not treated as an asset to such a policy approach. Beyond the goal of creating a specific labor market policy for recruiting talented individuals abroad, in order to counteract the brain drain of researchers and well educated individuals in general, the Diaspora policy should open interaction and cooperation between those who go abroad and those at home. This could include options for creating exchange programs for top researchers turning the brain drain to brain circulation (see Saxenian 2005) in order to increase knowledge transfers (see Kerr 2008), finance R\&D, attract risk capital (Plaza 2013), increase management capacities, or even for export promotion of innovative products produced in the homeland toward the Diaspora (see Rauch and Trindade, 2002). Thus, the goals of Greek innovation policy can be substantially accelerated if accompanied by a target oriented Diaspora policy. Moreover, as Saxenian and Sabel (2011, p. 107) point out, "the increased salience of Diaspora networks to economic development does also lie in their role in the design and construction of new institutions in their home countries. Over time they have the potential to create a context that supports self-sustaining growth". Given the vested interests at all levels, it will not be easy to implement such a policy plan. Further, it needs Greeks to change how they view themselves, developing from the pre-crisis self-image of an economy based on trade, tourism, and transfers to the vision of an innovative country. However, if Greek authorities commit themselves to the long-term goal of turning Greece into a European Silicon Valley, while communicating to the citizens its long-term benefits, reforms will find political support.

\section{Conclusion}

Greece's Euro-zone membership may have given the false impression that the economy might be driven by innovation. The Greek economy is not - it faces not only institutional but also severe structural deficits with a small industrial basis, low export ratio, small businesses and many closed professions. If decreasing labor costs and further institutional reforms were to be the only active policy, then Greece's future would be a low wage economy with an extended workbench of other innovative economies. Greece can only become prosperous if it also uses its comparative advantages beyond tourism, trade and agriculture.

Greece has a foundation of high quality research institutes at the beginning of the innovation chain, a handful of innovative companies who remained in Greece despite the high regulatory burden, as well as an impressive Diaspora in research, finance and business. As outlined in this article, Greek authorities need to make substantial 
investments into the innovation system, accompanied with further institutional reforms and an appropriate Diaspora approach in order to create an innovation policy which closes the gaps in the innovation chain. By doing so, the number of innovative companies would substantially increase, thus allowing Greece to find a path towards sustainable growth. However, if Greek authorities rest on their laurels of having slightly improved the institutional surrounding, researchers, businesses and capital will continue to stay away.

To this end we propose a ten-point policy plan designed to turn Greece into an innovation-based economy. Clearly the road to Orlando, Florida, (as a metaphor of investing in tourism only) would be an easier road to drive for the Greek government. However, the road to Orlando means keeping Greece at the lower end of income in Europe. Instead the road to San José offers the prospect of a significant increase in income for all Greeks.

Creating the right environment which encourages top Greek and non-Greek researchers to move to Greece, as well as supporting the Greek innovation chain, are critical to the future success and prosperity of the country. Recognized research with breakthrough discoveries will inherently attract venture capital. Attracting talent is a key factor in kick-starting an innovation economy. This will not only increase the number of jobs and salaries for highly qualified people, it will also provide prosperity to all. With this in mind, Greek decision makers must make clear that embarking on an innovation centered policy will not result in an instant improvement in the Greek economy - indeed it will take one or two decades at the minimum. However, the time to start is now, as the earlier these reforms are put into practice, the sooner the country will enter a sustainable economic growth path. And if all hidden assets are properly used, Greece might even become one of Europe's innovation leaders.

\section{Endnotes}

${ }^{1}$ For further information on the reform process and the development of the public deficit, see Tsakanikas 2012.

${ }^{2}$ It should emphasized though that there are reasons to assume that in Greece the share of people registering at the employment agency is lower than in many other EU-countries. The most important one is a much higher share of self-employed. Despite this limiting factor the current unemployment rate appears exceptionally high.

${ }^{3}$ See Bertoli et al. (2013). For Germany, for instance, this source observes that the inflow of Greek migrants almost doubled to more than 30,000 individuals in 2012 when compared to 2011. In addition, key agencies required to carry out the reform process, such as the Bank of Greece or the Regulatory Agency for Energy, are losing skilled staff at a time when their input is critical.

${ }^{4}$ According to Tsakanikas (2012) tourism contributed to GDP 15 percent in 2010, sustaining 740,000 jobs.

${ }^{5}$ The products with the highest turnover in Greece are beverages and milk products, see Brenke (2012).

${ }^{6}$ There are several reasons for this firm size culture. To a large extent, small firm size is the result of an adaptation according to which firms stay small in order to escape a predatory state and to realize tax avoidance. 
${ }^{7}$ For a real life example see the start-up story presented in the New York Times, Thomas (2011).

${ }^{8}$ See the recent report of Transparency International (2012), which ranked Greece as 94th in the world in its 2012 report with no evidence of improvement. For more anecdotal evidence, see Heyer (2012).

\section{Competing interests}

The IZA Journal of European Labor Studies is committed to the IZA Guiding Principles of Research Integrity. The authors declare that they have observed these principles.

\section{Authors' information}

Benedikt Herrmann is Team leader of the "Behavioural Economics Team" of the Joint Research Centre of the European Commission. Disclaimer: The views expressed are purely those of the author and may not in any circumstances be regarded as stating an official position of the European Commission.

Alexander Kritikos is Research Director at the German Institute for Economic Research (DIW Berlin), Professor of Economics at the University of Potsdam and Research Fellow of the IZA, Bonn and of the IAB, Nuremberg.

\section{Acknowledgement}

We would like to thank Marco Caliendo, Jonathan Gladstone, Adam Lederer, Georges Siotis, Aggelos Tsakanikas, Klaus F. Zimmermann, and the participants of the Athens conference on "Latent Sources of Growth Dynamics in Hellas" for their helpful and valuable comments and Anne Konrad for data preparation.

Responsible editor: Klaus F. Zimmermann

\section{Author details \\ ${ }^{1}$ Joint Research Centre of the European Commission, Ispra, Italy. ${ }^{2}$ German Institute for Economic Research (DIW Berlin), University of Potsdam, Potsdam, Germany.}

Received: 22 March 2013 Accepted: 11 September 2013

Published: 30 Sep 2013

\section{References}

Aghion P, Howitt P (1992) A model of growth through creative destruction. Econometrica 60:323-51 Ames E (1961) Research, invention, development and innovation. Am Econ Rev 51:370-381

Anderson B (2003) Rationale for Intellectual property rights in the Electronic Age, NewEconomy Handbook. Science, Elsevier

Anokhin S, Schulze WS (2009) Entrepreneurship, innovation, and corruption. J BusVenturing 24:465-476 Ariu A, Squicciarini MP (2013) The balance of brains - corruption and migration. EMBO Rep 14:502-504 Arrow KJ (1971) Essays in the Theory of Risk-Bearing. North-Holland Amsterdam

Audretsch DB, Feldman M (1996) R\&D spillovers and the geography of innovation and production. Am Econ Rev $86: 641-652$

Baumol W (2005) Education for innovation: entrepreneurial breakthroughs vs corporate incremental improvements. Innov Policy Econ 5:33-56

Baumol W, Schilling M (2008) Entrepreneurship. The New Palgrave Dictionary Econ, online version1-9

Bertoli S, Brücker H, Moraga JFH (2013) The European crisis and migration to Germany: expectations and the diversion of migration flows. IZA Disc, Paper No. 7170, Bonn

Bettencourt LMA, Lobo J, Strumsky D (2007) Invention in the city: increasing returns to patenting as a scaling function of metropolitan size. Res Policy 36:107-120

Bloom N, Genakos C, Sadun R, van Reenen J (2012) Management practices across firms and countries. Acad Manag Perspect 26:12-33

Brenke K (2012) The Greek economy needs a growth strategy. DIW Econ Bull 3:3-14

Buti M, Turrini A (2012) Slow but steady? External adjustment within the Eurozone starts working. VOX EU

Bygrave W, Timmons J (1992) Venture Capital at the Crossroads. Harvard Business School Press, Boston, MA

Caliendo M, Kritikos AS (2010) Start-ups by the Unemployed: characteristics, Survival and direct employment effects. Small Bus Econ 35:71-92

Caliendo M, Fossen F, Kritikos AS (2011) Personality characteristics and the decision to become and stay self-employed. IZA - Disc, Paper No. 5566

Callon M (1991) Techno-Economic Networks and Irreversibility. In: Law J (ed) A Sociology of Monsters: Essays on Power Technology and Domination., Routledge, London, pp 132-165

Cho H-J, Pucik V (2005) Relationship between innovativeness, quality, growth, profitability, and market value. Strateg Manag J 26:555-575

Cullmann A, Schmidt-Ehmcke J, Zloczysti P (2012) Innovation, R\&D efficiency and the impact of the regulatory environment: a two-stage semi-parametric DEA approach. Oxford Econ Pap 64:176-196

Diamond DW (1991) Monitoring and reputation: the choice between Bank Loans and directly placed debt. J Pol Econ 99:689-721

Drymiotis A (2012) The Monster of bureaucracy and what it costs, Kathimerini. 22:2012

Ellison G, Glaeser EL (1999) The Geographic concentration of industry: does natural advantage explain agglomeration. Am Econ Rev 89:311-316

European Commission (2009) Codification and recasting, Progress Report. Brussels

European Commission (2010) The Economic Adjustment Programme for Greece, Occasional Papers No. 68. Brussels 
EU Commission (2012) Innovation Union Scoreboard. http://ec.europa.eu/enterprise/policies/innovation/facts-figuresanalysis/innovation-scoreboard/

European Commission (2013) The Second Economic Adjustment Programme for Greece, third review, Occasional Papers No. 159. Brussels

Eurostat (2012) Statistics. http://epp.eurostat.ec.europa.eu/portal/page/portal/statistics/themes

Evans-Pritchard A (2012) Debt Crisis: Greek Euro Exit Looms Closer as Banks Crumble, The Telegraph, May 16

Fisher I (2007) Elementary Principles of Economics. Cosimo, New York

Freeman C (1987) Technology Policy and Economic Performance: Lessons from Japan. Pinter, London

Gennaioli N, La Porta L, Lopez-de-Silanes F, Shleifer A (2012) Human Capital and Regional Development. Q J Econ, first published online

Gilbert A, McDougall P, Audretsch D (2008) Clusters, knowledge spillovers and new venture performance: an empirical examination. J Bus Venturing 23:405-422

Gnyawali DR, Fogel DS (1994) Environments for entrepreneurship development: key dimensions and research implications. Entrepreneurship Theory Pract 18:43-62

Grant J, Ling T, Potoglou D, Culley DM (2011) A rapid review of the Greek research and development system. Rand Europe, Discussion Paper

Gruenhagen M, Berg H (2011) Modelling the antecedents of innovation-based growth intentions in entrepreneurial ventures - The role of perceived regulatory conditions in the German renewable energies and disease management industries. Int J Technol Policy Manage 11:220-249

Halme K, Cartalos O, Lähteenmäki-Smit K, Viljamaa K (2012) The Attractiveness of the EU for Top Scientists. ITRE Committee, European Parliament

Heyer JA (2012) Corruption Continues Virtually Unchecked in Greece. Spiegel Online Int, October 16: http://www.spiegel.de/international/europe/corruption-continues-virtually-unchecked-in-greece-a-861327.html

International Monetary Fund (2013) World Economic Outlook Database. http://www.imf.org/external/pubs/ft/weo/2013/ 01/weodata/index.aspx

Kanellopoulos N (2012) The Metropolitan Innovation Campus at Demokritos. Presentation at the Economist Round Table, Athens

Kerr W (2008) Ethnic scientific communities and international technology diffusion. Rev Econ Stat 90:518-537

Kloosterman RC (2003) Creating opportunities. Policies aimed at increasing openings for immigrant entrepreneurs in the Netherlands. Entrepreneurship Reg Dev 15:167-181

Knight FH (1921) Risk, Uncertainty and Profit. Houghton Mifflin, New York

Laursen $L$ (2012) European ministers back research-buddy plan. Nature, Dec. 18, online: http://www.nature.com/news/ european-ministers-back-research-buddy-plan-1.12080

Levie J, Autio E (2011) Regulatory burden, Rule of Law, and Entry of Strategic Entrepreneurs: An International Panel Study. J Manage Stud 8:1392-1419

Luthans F, Stajkovic AD, Ibrayeva E (2000) Environmental and psychological challenges facing entrepreneurial development in transitional economies. J World Bus 35:95-110

Mazzucato M (2011) The Entrepreneurial State. Renewal 19

Nelson RR (1993) National Innovation Systems: A Comparative Analysis. Oxford Univ, Press, Oxford

Nelson RR, Wright S (1992) The Rise and Fall of American Technological Leadership: the Postwar Era in Historical Perspective. J Econ Lit:1931-1964

OECD (2008) Product Market Regulation. http://stats.oecd.org/Index.aspx?Queryld=28994

OECD (2010) From European Economy. Paris, Occasional Papers No. 68, August

Pascual C, Sachini E (2012) 5 years of Excellence in the European Research Area 2007-2011: the case of Greece, national Documentation Centre.

Plaza S (2013) Diaspora Ressources and Policies. In: Constant AF, Zimmermann KF (eds) International Handbook on the Economics of Migration. Edward Elgar, Cheltenham, pp 505-529

Porter ME (1998) Clusters and the New Economics of Competition. Harv Bus Rev 76:77-90

Rauch JE, Trindade V (2002) Ethnic Chinese Networks in International Trade. Rev Econ Stat 84:116-130

Saxenian A (2005) From brain drain to brain circulation: Transnational communities and regional upgrading in India and China. Stud Comp Int Dev 40:35-61

Saxenian A, Sabel CF (2011) The new Argonauts and the Rise of Venture Capital in the Periphery. In: Audretsch D (ed) Handbook of Research on Innovation and Entrepreneurship. Edward Elgar, Cheltenham

Thomas L (2011) What's Broken in Greece? Ask an Entrepreneur. New York Times, January 29, online: http://www.nytimes.com/2011/01/30/business/30greek.html?pagewanted=all\&_r=0

Transparency International (2012) Corruption Perception Index. Online: http://www.transparency.org/cpi2012/results

Tsakanikas A (2012) The Greek Economy under Reform: a Sisyphean Task or a Victorious Way to Ithaka, IOBE Disc. Paper presented at the KAS Workshop

Tsiros G (2011) Greece innovates, joint publication by Eurobank Greece and SEV. Athens

Vassilatos V, Kollintzas T, Papageorgiou D (2012) An Explanation of the Greek Crisis: "The Insiders - Outsiders Society". CEPR Disc, Paper No. 8996

Veugelers R (2011) Mind Europe's Early-Stage Equity Gap. Bruegel Policy Contribution

WISTA (2011) The Economic Significance of Adlershof: Impact on added value, employment and tax revenues in Berlin. Berlin

Wong PK, Ho YP, Autio E (2005) Entrepreneurship, Innovation and Economic Growth: Evidence from GEM data. Small Bus Econ 24:335-350

World Bank (2012) Ease of Doing Business in Greece. Washington

10.1186/2193-9012-2-14

Cite this article as: Herrmann and Kritikos: Growing out of the crisis: hidden assets to Greece's transition to an innovation economy. IZA Journal of European Labor Studies 2013, 2:14 